\title{
Review
}

\section{Angiotensin converting enzyme inhibitors and angiotensin II antagonists as therapy in chronic liver disease}

Portal hypertension is the major complication of chronic liver disease and is associated with reduced survival. ${ }^{1}$ Pharmacological treatment is based on the premise that a sustained reduction in portal pressure will reduce the consequences of portal hypertension - that is, variceal bleeding, hepatic encephalopathy, and development of ascites. ${ }^{2}$

Non-selective $\beta$-blockers have proved effective in reducing portal pressure by lowering splanchnic blood inflow ${ }^{3}$ and are used in primary and secondary prevention of variceal bleeding. ${ }^{4}$ However, the mean decrease in portal pressure in response to propranolol is only approximately $15 \%{ }^{6}$ and one third of cirrhotic patients do not respond despite adequate blockade. ${ }^{7}$

During the last decade, increased knowledge of the pathophysiology of portal hypertension has resulted in the use of new pharmacological targets; most importantly for the reduction of intrahepatic resistance, which is now recognised to be due in part to activated stellate cell contraction (myofibroblasts). These represent mesenchymal cells that reside in the perisinusoidal space of Disse and resemble tissue pericytes, a cell type with smooth muscle features that is thought to regulate blood flow via pericapillary constriction. ${ }^{8}$ During liver injury they undergo "activation", characterised by production of increased amounts of extracellular matrix and are responsible for fibrosis. ${ }^{9}$ Moreover, experimental data provide strong evidence that activated stellate cells are contractile and may regulate sinusoidal blood flow, especially in the injured liver. ${ }^{10}$

The renin-angiotensin-aldosterone system (RAAS) is usually activated in patients with liver cirrhosis and this represents a homeostatic response to counterbalance the vasodilatation, arterial hypotension, and renal hypoperfusion observed in portal hypertension. ${ }^{11}$ Plasma renin activity (PRA) is elevated in cirrhotics and is correlated with the hepatic venous pressure gradient (HVPG). ${ }^{12}$ Angiotensin II (ANG-II) is considered a potential mediator of intrahepatic portal hypertension because its plasma levels are elevated in cirrhosis, ${ }^{13}$ and infusion of ANG-II induces a rise in portal pressure. ${ }^{14}$ Enhancement of the adrenergic vasoconstrictor influence on the portal system, ${ }^{15}$ direct contractile influence on activated stellate cells, ${ }^{16}$ and sodium and fluid retention induced by stimulation of aldosterone secretion ${ }^{17}$ are possible mechanisms that contribute to the portal hypertensive effect of ANG-II.

Hence, in theory, blockade of the RAAS by angiotensin converting enzyme (ACE) inhibitors/ANG-II receptor antagonists should be beneficial for improvement of fluid and salt secretion and reduce portal pressure in cirrhotic patients. ACE inhibitors block the RAAS preventing the conversion of inactive angiotensin I to active ANG-II, ${ }^{18}$ and may improve portal hypertension. However, concerns have been raised about their safety because of arterial hypotension and deterioration of renal function.

Orally active ANG-II receptor antagonists represent the most recent therapeutic development in the inhibition of RAAS. ${ }^{19}$ They are effective and safe in the control of systemic hypertension acting through specific AT1 receptors. Recently, the ANG-II receptor antagonists losartan and irbesartan have been studied in portal hypertensive patients with promising results. ${ }^{2021}$

We review the therapeutic effects of these drugs in cirrhotic patients.

\section{Effects on renal function}

SINGLE DOSE STUDIES (TABLE 1)

There are four studies involving 63 cirrhotics using ACE inhibitors. ${ }^{22-25}$ Captopril was used in 55 patients at doses ranging from 12.5 to $150 \mathrm{mg}$. In the first three studies captopril caused a significant reduction in glomerular filtration rate (GFR) with a consequent decrease in urinary volume and urinary sodium excretion, in association with significant decreases in mean arterial pressure (MAP) ${ }^{22-24}$ In the only randomised placebo controlled study, by Gentilini and colleagues, ${ }^{25}$ patients who had arterial hypotension after a single intravenous dose of captopril were excluded from the analysis so as to elucidate if the deleterious renal effects in the previous studies were secondary to arterial hypotension. However, captopril still induced a significant decrease in GFR and urinary sodium excretion in patients with or without ascites. Therefore, ANG-II contributes to the maintenance of renal haemodynamics in cirrhosis and consequently ACE inhibitors are harmful.

A subsequent study of $10 \mathrm{mg}$ of enalapril in eight cirrhotic patients ${ }^{22}$ showed increased hourly urine volume and renal sodium excretion during the first two hours, but 24 hour urinary volume was unchanged.

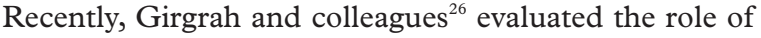
ANG-II in sodium homeostasis in nine preascitic cirrhotic patients using losartan, its receptor antagonist. A doseresponse study showed that $7.5 \mathrm{mg}$ was the optimal dose to produce natriuresis without systemic hypotension, normalising renal sodium without changes in systemic or renal haemodynamics. In the absence of GFR or renal plasma flow (RPF) changes, one would speculate that ANG-II has a direct sodium retaining effect on the renal tubule. However, baseline systemic ANG-II levels were significantly lower in preascitic cirrhotics compared with controls. The authors suggested that intrarenal production of ANG-II or increased sensitivity of preascitic cirrhotics to the sodium retaining effect of ANG-II would explain this discrepancy. Alternatively, losartan could have reduced portal pressure and thus improved sodium retention, without a direct effect on renal haemodynamics.

MULTIPLE DOSE STUDIES (TABLE 2)

In 1983, Saruta and colleagues ${ }^{27}$ used the ACE inhibitor SQ14225 in six cirrhotics for seven days. ANG-II and plasma aldosterone levels decreased and PRA increased markedly. Although systemic blood pressure was lowered, urinary sodium excretion increased significantly in five of

Abbreviations used in this paper: ANG-II, angiotensin II; ACE, angiotensin converting enzyme; GFR, glomerular filtration rate; HSCs, hepatic stellate cells; HVPG, hepatic venous pressure gradient; MAP, mean arterial pressure; PRA, plasma renin activity; RAAS, renin-angiotensin-aldosterone system; RPF, renal plasma flow; WHVG, wedged hepatic venous gradient. 
Table 1 Single dose studies of the effects of angiotensin converting enzyme inhibitors/angiotensin II receptor antagonists on renal function, urine output, and sodium excretion

\begin{tabular}{|c|c|c|c|c|c|c|c|}
\hline Author/year & No patients & Ascites & $\begin{array}{l}\text { Drug dose } \\
\text { (mg) }\end{array}$ & Urinary Na output & $\begin{array}{l}\text { Creatinine clearance or } \\
\text { GFR (ml/min) }\end{array}$ & Urine volume & $M A P(m m H g)$ \\
\hline Girgrah, $2000^{26}$ & 9 & No & $\begin{array}{l}\text { Losartan } 7.5 \\
\text { orally }\end{array}$ & $\begin{array}{l}154(8) \text { to } 202(12) \\
\mathrm{mmol} / \mathrm{day}^{\star}\end{array}$ & $90(9)$ to $92(11)$ & NA & 88 (3) to $84(4)$ \\
\hline Pariente, $1985^{23}$ & 6 & Yes & $\begin{array}{l}\text { Captopril } 25 \\
\text { orally }\end{array}$ & $\begin{array}{l}\text { In } 4 \text { remained }<5 \mu \mathrm{mol} / \mathrm{min} \text {. } \\
\text { In } 2 \text {, drop from } 198 \text { and } 200 \\
\text { to }<5 \mu \mathrm{mol} / \mathrm{min}\end{array}$ & $9.3(23)$ to $71(2.4)^{\star}$ & $\begin{array}{l}1.9(0.4) \text { to } 1(0.4) \\
\mathrm{ml} / \mathrm{min}^{\star}\end{array}$ & $\begin{array}{l}87(10.6) \text { to } 72.5 \\
(7.3)^{\star}\end{array}$ \\
\hline $\begin{array}{l}\text { Daskalopoulos, } \\
1987^{24}\end{array}$ & 11 & Yes & $\begin{array}{l}\text { Captopril } \\
50-150 \text { orally }\end{array}$ & $\begin{array}{l}2.7(1) \text { to } 0.48(0.21) \\
\mathrm{mmol} / \mathrm{h}^{\star}\end{array}$ & $\begin{array}{l}\text { Inulin clearance } 73(8) \\
\text { to } 76(7)\end{array}$ & $\begin{array}{l}377(55) \text { to } 182(42) \\
\mathrm{ml} / \mathrm{h}^{\star}\end{array}$ & $88(1)$ to $74(1)^{\star}$ \\
\hline \multirow[t]{2}{*}{ Ohnishi, $1990^{22}$} & 8 & Yes & $\begin{array}{l}\text { Captopril } 50 \\
\text { orally }\end{array}$ & $\begin{array}{l}114.8(12.2) \text { to } 85.6(10.2) \\
\mathrm{mmol} / \text { day }\end{array}$ & NA & $\begin{array}{l}1800(170.6) \text { to } 1422 \\
(143.2) \mathrm{ml} / \text { day }\end{array}$ & 90.5 to $76^{\star}$ \\
\hline & 8 & Yes & $\begin{array}{l}\text { Enalapril } 10 \\
\text { orally }\end{array}$ & $\begin{array}{l}103.2(12.1) \text { to } 113.7(32.7) \\
\mathrm{mmol} / \text { dayt }\end{array}$ & NA & $\begin{array}{l}1940(168.3) \text { to } 2192.5 \\
(226.9) \mathrm{ml} / \text { dayt }\end{array}$ & 92.7 to $82^{\star}$ \\
\hline \multirow[t]{2}{*}{ Gentilini, $1993^{25}$} & 30 & $\begin{array}{l}\text { Yes } \\
(\mathrm{n}=9)\end{array}$ & $\begin{array}{l}\text { Captopril } \\
12.5 \\
\text { intravenous }\end{array}$ & $\begin{array}{l}43.8 \text { (placebo) v } 30.6 \text { (drug) } \\
\mu \mathrm{mol} / \mathrm{min}^{\star}\end{array}$ & $\begin{array}{l}108(7) \text { (placebo) } v 78 \\
(9)(\text { drug })^{\star}\end{array}$ & $\begin{array}{l}2.7(0.7) \text { (placebo) to } 2.1 \\
(0.4)(\text { drug }) \mathrm{ml} / \mathrm{min}\end{array}$ & Reduction $<5$ \\
\hline & & $\begin{array}{l}\text { No } \\
(n=21)\end{array}$ & $\begin{array}{l}\text { Captopril } \\
12.5 \\
\text { intravenous }\end{array}$ & $\begin{array}{l}40.3(6.1) \text { (placebo ) v } 29.3 \\
\text { (7.6) (drug) } \mu \mathrm{mol} / \mathrm{min}^{\star}\end{array}$ & $\begin{array}{l}102(4) \text { (placebo) } v 88 \\
\text { (3) }(\text { drug) }\end{array}$ & $\begin{array}{l}3.9 \text { (0.3) (placebo) to } 4.2 \\
(0.3) \text { (drug) } \mathrm{ml} / \mathrm{min}\end{array}$ & Reduction $<5$ \\
\hline
\end{tabular}

Values are mean (SD).

$\mathrm{NA}$, data not given in the studies or not applicable; GFR, glomerular filtration rate; MAP, mean arterial pressure.

${ }^{\star}$ Statistically significant compared with baseline; †statistically significant compared with captopril.

six patients, and ascites improved but did not disappear. Since then, five studies ${ }^{28-32}$ comprising 60 patients with ascites have been reported using captopril (9-75 mg/day) given for 3-21 days. In three studies, ${ }^{28-30}$ captopril caused a significant reduction in body weight, enhancement of urinary sodium excretion, and improvement of fluid balance in the majority of patients. However, Wood and colleagues ${ }^{31}$ used captopril for three days in four patients with resistant ascites and reported falls in MAP with subsequent falls in GFR, decreases in sodium excretion, and no improvement in ascites. These authors suggested that ACE inhibitors have little place in the treatment of patients with resistant ascites and may be harmful. The only randomised placebo controlled study was performed by Tsai and colleagues $^{32}$ and included 50 patients with ascites. PRA became significantly raised in the captopril group, and this was considered as adequate blockade of ACE. Nevertheless, there was no significant change in urine volume, creatinine clearance, or RPF, and the improvement in urine sodium excretion was not significant.

Enalapril was used in two small studies ${ }^{33} 34$ with 18 patients. In one, ${ }^{33}$ a significant increase in urinary volume and sodium excretion was seen. In both studies creatinine clearance improved significantly.

Evaluation of the above studies is difficult because most were neither placebo controlled nor randomised. Furthermore, as patient characteristics differed considerably between studies (for example, Child-Pugh class, presence

Table 2 Multiple dose studies of the effects of angiotensin converting enzyme inhibitors on renal function, urine output, and sodium excretiont

\begin{tabular}{|c|c|c|c|c|c|c|c|}
\hline Author/year & $\begin{array}{l}\text { No } \\
\text { patients }\end{array}$ & Drug dose (mg/day) & $\begin{array}{l}\text { Duration } \\
\text { (day) }\end{array}$ & $\begin{array}{l}\text { Urinary Na output } \\
\text { (mmol/day) }\end{array}$ & $\begin{array}{l}\text { Creatinine clearance } \\
\text { or GFR ( } \mathrm{ml} / \mathrm{min})\end{array}$ & Urine volume (ml/day) & $M A P(m m H g)$ \\
\hline $\begin{array}{l}\text { Saruta, } \\
1983^{27}\end{array}$ & 6 & SQ14225 $75 \mathrm{mg}$ & 7 & $\begin{array}{l}100(5) \text { to } 165(16) \text { in } \\
5 \text { of } 6^{\star}\end{array}$ & Unchanged & $\begin{array}{l}1400(210) \text { to } 1800 \\
(180)^{\star}\end{array}$ & $92.6(7)$ to $87(7)$ \\
\hline $\begin{array}{l}\text { Brunkorst, } \\
1989^{28}\end{array}$ & 14 & $\begin{array}{l}\text { Captopril } 12.5 \mathrm{mg} \text { for } 5 \\
\text { days then } 25 \mathrm{mg} \text { for } 5 \\
\text { days }\end{array}$ & 10 & 70 to $125^{\star}$ & $\begin{array}{l}53.7(7.8) \text { to } 66.9 \\
(15.1)\end{array}$ & $\begin{array}{l}\text { Fluid balance: }+200 \text { to } \\
-600^{\star}\end{array}$ & $84(2.9)$ to $78.4(2.9)$ \\
\hline Ibarra, $1992^{29}$ & 9 & Captopril $75 \mathrm{mg}$ & 21 & $\begin{array}{l}36.7(9.5) \text { to } 103 \\
(13.8) 7 \text { of } 9 \text { patients }\end{array}$ & NA & NA & $\begin{array}{l}86.9(2.6) \text { to } 80.2 \\
(3.7)\end{array}$ \\
\hline $\begin{array}{l}\text { Van Vliet, } \\
1992^{30}\end{array}$ & 8 & $\begin{array}{l}\text { Captopril from } 9 \text { to } \\
37.5 \mathrm{mg}\end{array}$ & 20 & $\begin{array}{l}72.8(35.2) \text { to } 1128.5 \\
(63.5) \text { in } 4 \\
\text { responders } \\
40.9 \text { (35) to } 42.4(32) \\
\text { in } 4 \text { non-responders }\end{array}$ & NA & $\begin{array}{l}1207(456) \text { to } 1646 \\
(395) \text { in } 4 \text { responders } \\
1107(334) \text { to } 1375 \\
(424) \text { in } 4 \\
\text { non-responders }\end{array}$ & $\begin{array}{l}79.8(7.3) \text { to } 72.6(9) \\
\text { in } 4 \text { responders } \\
86.3(5.9) \text { to } 84.2 \\
(9.4) \text { in } 4 \\
\text { non-responders }\end{array}$ \\
\hline Wood, $1985^{31}$ & 4 & $\begin{array}{l}\text { Captopril from } 18.75 \text { to } \\
37.5 \mathrm{mg}\end{array}$ & 3 & 14.25 to $6.5 \ddagger$ & 70 to $46 \ddagger$ & NA & 87 to $78 \ddagger$ \\
\hline Tsai, $1996^{32}$ & $\begin{array}{l}25 \\
25\end{array}$ & $\begin{array}{l}\text { Captopril } 6.25 \text { tds } \\
\text { Placebo }\end{array}$ & $\begin{array}{l}14 \\
14\end{array}$ & $\begin{array}{l}20(5) \text { to } 26(6) \\
21(6) \text { to } 18(4)\end{array}$ & $\begin{array}{l}45(11) \text { to } 40(10) \\
41(10) \text { to } 38(11)\end{array}$ & $\begin{array}{l}790(111) \text { to } 725(85) \\
653(78) \text { to } 750(97)\end{array}$ & $\begin{array}{l}88(3) \text { to } 86(4) \\
86(2) \text { to } 85(3)\end{array}$ \\
\hline $\begin{array}{l}\text { Ohnishi, } \\
1994^{33}\end{array}$ & 10 & Enalapril $10 \mathrm{mg}$ & 8 & 73 to $110 \ddagger^{\star}$ & 47 to $60 \ddagger^{\star}$ & 1800 to $2300 \ddagger^{\star}$ & NA \\
\hline $\begin{array}{l}\text { Amarapurkar, } \\
1994^{34}\end{array}$ & 8 & Enalapril $10 \mathrm{mg}$ & 7 & NA & $\begin{array}{l}46.5(15.4) \text { to } 73.2 \\
(19.7)^{\star}\end{array}$ & NA & NA \\
\hline
\end{tabular}

Values are mean (SD).

NA, data not given or not applicable; GFR, glomerular filtration rate; MAP, mean arterial pressure.

$\ddagger$ Numbers obtained by measurement and/or calculation on figures.

* Statistically significant.

†All patients had ascites. 
Table 3 Studies of the effects of angiotensin converting enzyme inhibitors on portal pressure

\begin{tabular}{|c|c|c|c|c|c|c|c|}
\hline Author/year & $\begin{array}{l}\text { No } \\
\text { patients }\end{array}$ & Drug dose (mg) & Duration & WHVP $(m m ~ H g)$ & $F H V P(m m ~ H g)$ & $H V P G(m m ~ H g)$ & $M A P(m m H g)$ \\
\hline $\begin{array}{l}\text { Eriksson, } \\
1984^{40}\end{array}$ & 7 & $\begin{array}{l}\text { Captopril } 12.5-25 \\
\mathrm{mg}\end{array}$ & Single oral & $22(2)$ to $19(2)$ & 8 to $5 \ddagger$ & $14(2)$ to $13(2)$ & $93(3)$ to $79(7)^{\star}$ \\
\hline $\begin{array}{r}\text { Pariente, } \\
1985^{23}\end{array}$ & 6 & Captopril $12.5 \mathrm{mg}$ & Single oral & NA & NA & $\begin{array}{l}19.7(3.6) \text { to } 18.8 \\
(3.7)\end{array}$ & $87(10.6)$ to $72.5(7.3)^{\star}$ \\
\hline Ibarra, $1992^{29}$ & 9 & Captopril $25 \mathrm{mg}$ & Single oral & $\begin{array}{l}22.9(2.7) \text { to } 20.7 \\
(2.4)\end{array}$ & $15(1.8)$ to $12.1(0.9)$ & $7.58(1.5)$ to $8.58(2)$ & $86.9(2.6)$ to $77(1.9)^{\star}$ \\
\hline \multirow[t]{2}{*}{ Tsai, $1996^{32}$} & 25 & Captopril $18.75 \mathrm{mg}$ & 2 weeks & NA & NA & $\begin{array}{l}17.2(1.3) \text { to } 17.5 \\
(1.2)\end{array}$ & 88.3 (3) to $86(4)$ \\
\hline & 25 & Placebo & 2 weeks & NA & NA & $\begin{array}{l}17.6(1.1) \text { to } 17.8 \\
(1.1)\end{array}$ & $86(2)$ to 85 (3) \\
\hline Ibarra, $1992^{29}$ & 9 & Captopril $75 \mathrm{mg}$ & 3 weeks & $\begin{array}{l}22.9(2.7) \text { to } 18.8 \\
(2.9)\end{array}$ & 15 (1.8) to $9.4(0.5)$ & $7.6(1.5)$ to $9.3(2.7)$ & $86.9(2.6)$ to $80.2(3.7)$ \\
\hline \multirow[t]{2}{*}{$\begin{array}{r}\text { Svoboda, } \\
1992^{42}\end{array}$} & 12 & Enalapril $20 \mathrm{mg}$ & 12 weeks & $\begin{array}{l}25.5(4.8) \text { to } 21.3 \\
(4.8)^{\star}\end{array}$ & $8.0(2.8)$ to $8.6(2.3)$ & $17(6)$ to $12.6(3.4)^{\star}$ & $14.1(4.1)$ to 12.5 (3.8) \\
\hline & 13 & Placebo & 12 weeks & $\begin{array}{l}22.8(7.1) \text { to } 23.3 \\
(6.7)\end{array}$ & $8.7(4.3)$ to $8.2(3.8)$ & $\begin{array}{l}14.2(5.1) \text { to } 15.2 \\
(3.4)\end{array}$ & $13.6(4)$ to $12.8(4.2)$ \\
\hline $\begin{array}{l}\text { Chiang, } \\
1995^{41}\end{array}$ & 20 & Enalaprilat $2.5 \mathrm{mg}$ & $\begin{array}{l}\text { Single } \\
\text { intravenous }\end{array}$ & $\begin{array}{l}32.1(5.1) \text { to } 25.6 \\
(7.2)^{\star}\end{array}$ & $\begin{array}{l}11.2(3.7) \text { to } 10.7 \\
(3.7)^{\star}\end{array}$ & $\begin{array}{l}21(4.3) \text { to } 16.1 \\
(4.5)^{\star}\end{array}$ & $\begin{array}{l}94.1(11.2) \text { to } \\
85.6(13.8)^{\star}\end{array}$ \\
\hline
\end{tabular}

Values are mean (SD).

NA, data not available; WHVP, wedged hepatic venous pressure; FHVP, free hepatic venous pressure; HVPG, hepatic venous pressure gradient; MAP, mean arterial pressure.

${ }^{\star}$ Statistically significant.

$\ddagger$ Numbers obtained by measurement and/or calculation on figures.

of ascites, salt restriction, use of diuretics, and renal function impairment) it is difficult to make comparisons.

Single doses of captopril worsen renal function ${ }^{22-25}$ but this reflects only the immediate haemodynamic effects, which may not be the case with long term treatment. Indeed, some neurohormonal changes (for example, decrease in aldosterone levels) are evident only after long term treatment, as highlighted by Ohnishi and colleagues. ${ }^{33}$ There are five multiple dose studies showing that captopril and enalapril enhance renal sodium excretion. ${ }^{28-30} 3334$ However, it is noteworthy that baseline urinary sodium excretion was more than $70 \mathrm{mmol} /$ day in all of these studies compared with the very low baseline sodium excretion in the studies reporting no improvement. ${ }^{31}{ }^{32}$ It is possible that only patients with an earlier stage of liver disease, and hence less renal impairment, may benefit from the use of ACE inhibitors.

However, in decompensated cirrhotics there is reduced peripheral resistance and a compensatory increase in plasma volume and cardiac output. ${ }^{35}$ Under these conditions, activation of RAAS plays a critical role in maintaining arterial pressure and in autoregulation of GFR, which maintains GFR at near constant values despite a reduction in renal perfusion pressure. ${ }^{36}$ Therefore, administration of ACE inhibitors or ANG-II antagonists in these patients would result in deterioration of renal function and worsening of sodium excretion.

Conversely, in patients with preascitic cirrhosis, in whom a subtle sodium handling abnormality is found, it is still not entirely clear if this is due to compensatory activation of the RAAS counteracting the consequences of hyperdynamic circulation $^{37}$ or if the RAAS plays a crucial pathogenetic role in abnormal sodium handling. ${ }^{38}$ Girgrah and colleagues $^{26}$ emphasised the primary role of ANG-II in increased renal sodium reabsorption to explain the positive role of losartan in normalisation of sodium handling. Conversely, in the recent study by Helmy and colleagues ${ }^{39}$ (despite the increase in plasma ANG-II concentrations in preascitic cirrhotics) there was still hyporesponsiveness of the peripheral vessels after administration of losartan. This supports the concept that ANG-II does not have a role in maintenance of vascular tone in these patients. Therefore, use of ANG-II inhibitors could be beneficial in early cirrhosis to counteract the effects of raised ANG-II levels in renal sodium handling and would not have deleterious effects on systemic haemodynamics.

\section{Effects on portal pressure}

ACE INHIBITORS

Captopril has been evaluated in four studies (table 3). ${ }^{23} 293240$ In three (22 patients), captopril was given as a single oral dose..$^{23} 29$ No significant change in HVPG was detected in any study. In addition, there was a small but significant decrease in MAP with deterioration of systemic haemodynamics. Ibarra and colleagues ${ }^{29}$ evaluated captopril after three weeks of administration, reporting a significant reduction in free hepatic venous pressure while wedged hepatic venous pressure (WHVP) decreased less. Therefore, HVPG was increased, although this was not significant. Finally, in the study of Tsai and colleagues, ${ }^{32}$ captopril given for 14 days had no effect on the systemic or hepatic circulation.

The efficacy of enalapril in the blockade of RAAS and therefore in reducing portal pressure was evaluated in two small studies (table 3). Chiang and colleagues ${ }^{41}$ used 2.5 $\mathrm{mg}$ of enalaprilat, the active metabolite of enalapril, by intravenous infusion, in 20 patients with cirrhosis associated with hepatitis B. HVPG was reduced significantly within 30 minutes in 13 of 20 patients. Although MAP fell, liver and renal function did not change significantly. Svoboda and colleagues ${ }^{42}$ reported a significant drop in HVPG after three months of administration of enalapril in 12 cirrhotics undergoing long term sclerotherapy; no reduction in HVPG was found in 13 controls who received placebo. Systemic haemodynamics and liver function did not change.

Only two of the above studies were randomised with the use of placebo ${ }^{32} 42$ but the small number of patients with different clinical characteristics makes it difficult to generalise. However, similar to the absence of renal effects, captopril failed to reduce portal pressure in all four studies. ${ }^{2329} 3240$ Interestingly, enalapril proved effective in two small studies (32 patients) although there was a poor response in patients with severe liver dysfunction (Child 
Table 4 Studies of the effects of angiotensin II receptor antagonists on portal pressure

\begin{tabular}{|c|c|c|c|c|c|c|c|}
\hline Author/year & No patients & Drug dose (mg) & Duration & WHVP $(m m \mathrm{Hg})$ & $F H V P(m m H g)$ & $H P V G(m m H g)$ & $M A P(m m H g)$ \\
\hline Arroyo, $1981^{45}$ & 14 & $\begin{array}{l}\text { Saralasin 1-2.5 } \\
\mathrm{mg} / \mathrm{kg} / \mathrm{min}\end{array}$ & $\begin{array}{l}\text { Single } \\
\text { infusion }\end{array}$ & $\begin{array}{l}17.2(0.9) \text { to } 13.7 \\
(0.9)^{\star}\end{array}$ & NA & NA & $\begin{array}{l}76.8(4) \text { to } 61.1 \\
(5.9)^{\star}\end{array}$ \\
\hline \multirow[t]{4}{*}{ Schneider, $1999^{20}$} & $\begin{array}{l}30(\mathrm{HVPG} \geqslant 20 \\
\mathrm{mm} \mathrm{Hg})\end{array}$ & Losartan $25 \mathrm{mg}$ & 1 week & $\begin{array}{l}29.5(3.8) \text { to } 18 \\
(4.8)^{\star}\end{array}$ & $\begin{array}{l}4.8(2.2) \text { to } 4.8 \\
(2.4)\end{array}$ & $\begin{array}{l}24.8(2.6) \text { to } 13.1 \\
(4.1)^{\star}\end{array}$ & $\begin{array}{l}89.1(6.8) \text { to } 86 \\
(7.8)^{\star}\end{array}$ \\
\hline & $\begin{array}{l}15(\mathrm{HVPG} \geqslant 20 \\
\mathrm{mm} \mathrm{Hg})\end{array}$ & Placebo & 1 week & $\begin{array}{l}28.8 \text { (3.3) to } 27.9 \\
(3.8)\end{array}$ & $\begin{array}{l}4.9(2.2) \text { to } 4.8 \\
(2.1)\end{array}$ & $\begin{array}{l}23.9 \text { (4.1) to } 23.1 \\
(4.2)\end{array}$ & $\begin{array}{l}88.3(5.5) \text { to } 88.6 \\
(4.5)\end{array}$ \\
\hline & $\begin{array}{l}15 \text { (HVPG }<20 \\
\mathrm{~mm} \mathrm{Hg})\end{array}$ & Losartan $25 \mathrm{mg}$ & 1 week & $\begin{array}{l}22.1(2.6) \text { to } 14.1 \\
(2.9)^{\star}\end{array}$ & $\begin{array}{l}4.2(1.6) \text { to } 4.1 \\
(1.5)\end{array}$ & $\begin{array}{l}17.9(1.4) \text { to } 10 \\
(2.7)^{\star}\end{array}$ & $\begin{array}{l}90.9(5.5) \text { to } 87.4 \\
(4.6)^{\star}\end{array}$ \\
\hline & $\begin{array}{l}10 \text { (HVPG }<20 \\
\mathrm{~mm} \mathrm{Hg})\end{array}$ & Placebo & 1 week & $\begin{array}{l}17.7(1.3) \text { to } 16.9 \\
(1.5)\end{array}$ & $\begin{array}{l}4.3(1.9) \text { to } 4.5 \\
(1.9)\end{array}$ & $\begin{array}{l}17.7(1.3) \text { to } 16.9 \\
(1.5)\end{array}$ & $\begin{array}{l}93.3(6.7) \text { to } 91.7 \\
(4.5)\end{array}$ \\
\hline $\begin{array}{l}\text { Debernardi-Venon, } \\
1999^{21}\end{array}$ & 119 & Irbesartan $300 \mathrm{mg}$ & 8 weeks & NA & NA & $\begin{array}{l}18.3(4) \text { to } 14.5 \\
(3.4)^{\star}\end{array}$ & NA \\
\hline \multirow[t]{2}{*}{ Schepke, $2000^{49}$} & $14 \S$ & Irbesartan $150 \mathrm{mg}$ & 1 week & NA & NA & $\begin{array}{l}18.3(4) \text { to } 14.7 \\
(3.7)^{\star}\end{array}$ & $\begin{array}{l}81.3(16) \text { to } 76.7 \\
(14.7)\end{array}$ \\
\hline & 16 & Placebo & 1 week & NA & NA & $18(3.9)$ to $17.6(3.6)$ & $\begin{array}{l}81.8(8.6) \text { to } 87.1 \\
(9.9)\end{array}$ \\
\hline
\end{tabular}

Values are mean (SD).

NA, data not available; WHVP, wedged hepatic venous pressure; FHVP, free hepatic venous pressure; HVPG, hepatic venous pressure gradient; MAP, mean arterial pressure.

${ }^{\star}$ Statistically significant.

TOne stopped due to side effects.

§Four stopped due to side effects.

C). This may be attributed to inadequate dosage to counteract the high RAAS in these patients. However, the significant changes in MAP after enalapril raise the possibility that the potential adverse effects may outweigh the potential benefits in larger doses. These opposite results for captopril compared with the enalapril studies are not easy to understand. In one study, enalapril was more effective in preventing the postural induced increase in aldosterone concentrations compared with captopril. ${ }^{43}$ This may reflect more complete inhibition of ACE. Whether such differences result in different clinical effects is debatable.

\section{ANG-II INHIBITORS}

During long term ACE inhibition, alternative enzymatic pathways to ACE, such as trypsin and cathepsin, can also convert angiotensin I to ANG-II. ${ }^{19}$ This could explain why ACE inhibitors do not reduce portal pressure in cirrhotics. ${ }^{44}$ Moreover, ACE participates in the breakdown of bradykinin to inactive peptides. Accumulation of bradykinin after ACE inhibition would worsen the systemic hyperdynamic circulation in cirrhosis and thus outweigh the beneficial effects of ACE inhibitors on portal pressure.

The development of specific antagonists of ANG-II receptors has renewed interest in the role of RAAS activation in portal hypertension and the potential benefit from its inhibition. Early in 1981, Arroyo and colleagues ${ }^{45}$ reported that intravenous infusion of saralasin (a short acting ANG-II antagonist) induced a significant reduction in WHVP but it correlated significantly with the decrease in MAP.

Recently, Schneider and colleagues ${ }^{20}$ evaluated seven days of $25 \mathrm{mg}$ of the orally active ANG-II receptor antagonist losartan in 45 cirrhotics (table 4 ): 30 had severe (HVPG $\geqslant 20 \mathrm{~mm} \mathrm{Hg}$ ) and 15 moderate portal hypertension (HVPG $<20 \mathrm{~mm} \mathrm{Hg}$ ). Losartan caused a significant $(\mathrm{p}<0.001)$ decrease in HVPG in patients with both severe $(-46.8(15.5) \%)$ and moderate $(-44.1$ $(14.7) \%$ ) portal hypertension while no significant reduction was found in controls. Losartan caused a slight, albeit statistically significant, decrease in MAP in both groups of patients ( -3.1 (5.0) and -3.5 (4.3) $\mathrm{mm} \mathrm{Hg}$, respectively). Liver and renal function did not deteriorate, and the authors concluded that losartan was safe and highly effective in the treatment of portal hypertension. It should be noted that only three of 45 cirrhotics had Child-Pugh grade C (25 Child A, 17 Child B). A further study published in abstract form by Debernardi-Venon and colleagues ${ }^{21}$ supported the beneficial effect of ANG-II receptor antagonists in the reduction in portal pressure (table 4): 11 cirrhotics given $300 \mathrm{mg}$ of irbesartan daily for two months had a significant reduction in HVPG (mean -3.7 $\mathrm{mm} \mathrm{Hg},-20.7 \%$ ) without renal side effects. Only one patient developed symptomatic hypotension.

Irbesartan does not require hepatic metabolism to an active metabolite such as losartan and can be administered in normal dosage despite hepatic impairment.

Although the results of the study of Schneider and colleagues $^{20}$ appear impressive, a number of concerns have been raised. ${ }^{46}$ Firstly, despite the mean reduction in HVPG being approximately $45 \%$ (the most effective reduction in portal pressure described for any portal hypotensive agent), there was no effect on systemic pressure. Secondly, the study was neither randomised nor blinded, and both of these methodological considerations are important to internally validate the results. Thirdly, the same dose (25 $\mathrm{mg}$ ) of losartan in another study caused a decrease in blood pressure of $10-12 \mathrm{~mm} \mathrm{Hg}$ in patients with arterial hypertension and 7-8 $\mathrm{mm} \mathrm{Hg}$ in subjects with normal blood pressure. ${ }^{47}$ Surprisingly, the MAP reduction in Schneider's study was only $3 \mathrm{~mm} \mathrm{Hg} .{ }^{20}$ One proposed mechanism for the reduction in portal pressure by ANG-II antagonists is a decrease in portal blood flow caused by reflex splanchnic arterial vasoconstriction which in turn is caused by the reduction in blood pressure. This mode of action in cirrhotics, with an already marked peripheral vasodilatation and resultant decrease in effective blood volume, should induce further deterioration in systemic haemodynamics with deleterious effects on renal function.

However, Schneider et al suggested that the reduction in portal pressure with losartan was mostly due to decreased resistance of the intrahepatic vasculature without major effects on systemic haemodynamics. ${ }^{20}$ However, a study using isolated perfused cirrhotic rat liver ${ }^{48}$ showed that only $20-30 \%$ of intrahepatic resistance in cirrhosis is amenable to pharmacological manipulation and therefore only half of the average $45 \%$ reduction in portal pressure observed with losartan theoretically can be attributed to a decrease in intrahepatic resistance.

The above concerns and putative explanations for the reduction in portal pressure surfaced in the first double 
blind placebo controlled study using the ANG-II antagonist irbesartan by Schepke and colleagues, ${ }^{49}$ recently published in abstract form (table 4). Thirty cirrhotic patients with portal hypertension were randomised to receive either $150 \mathrm{mg}$ of irbesartan once daily or placebo for one week. Irbesartan caused a significant reduction in HVPG (mean reduction 16.7 (23)\%) which was less pronounced compared with losartan. ${ }^{20}$ However, in $21 \%$ of patients, treatment had to be discontinued due to arterial hypotension. Moreover, in those who completed the study there was reduced creatinine clearance.

In a further twist to this series of observations, a recently published study by Bataller and colleagues ${ }^{50}$ showed that activated human stellate cells (HSCs) express ANG-II receptors (AT1 subtype) and that binding of ANG-II to AT1 receptors induces contraction and proliferation. The effects of ANG-II were undetectable in quiescent stellate cells, suggesting that activated stellate cells may be a target for ANG-II. Previous reports on the presence of ANG-II receptors in activated HSCs provided conflicting results ${ }^{16} 51$ but this could be attributed to differences in the presence or number of ANG-II receptors among species or to differences in methodology. Interestingly, in a previous study, ${ }^{52}$ systemic infusion of ANG-II resulted in significant cardiac and renal fibrosis but no fibrogenic response was detected in the liver. Further investigation is required to elucidate the in vivo effects of ANG-II in liver injury and hepatic fibrogenesis. ${ }^{53}$ This effect, rather than that on portal hypertension, may be of considerable clinical relevance; for example, in patients with chronic hepatitis who would have no, or at least minimal, activation of the RAAS. If inhibition of the contractile and proliferative properties of HSCs by losartan and other ANG-II receptor antagonists is confirmed in animal models, this would open up a new therapeutic avenue in the precirrhotic patient.

\section{Conclusion}

In the study of Schneider and colleagues ${ }^{20}$ which demonstrated a marked reduction in HVPG with losartan and the most marked reduction in portal pressure by a drug, most patients were well compensated cirrhotics. Current data suggest that the RAAS does not have an important role in maintaining basal vascular tone in the early stages of cirrhosis ${ }^{39}$ and probably not at all in chronic hepatitis. Thus administration of ANG-II inhibitors may not have a deleterious effect on systemic or renal haemodynamics in these groups of patients. Conversely, in cirrhotics with established cirrhosis or end stage liver disease, there is marked activation of the RAAS to compensate for peripheral vasodilatation and to maintain arterial pressure. In this setting, the potentially beneficial effect of ANG-II inhibitors in reducing intrahepatic resistance (via relaxation of activated stellate cells (myofibroblasts)) would be counterbalanced by their deleterious effects on systemic and renal haemodynamics.

Thus ANG-II inhibitors may turn out to be useful drugs for patients with chronic hepatitis without significant portal hypertension to postpone the development of portal hypertension, but they may also suppress stellate cell proliferation (that is, act as an antifibrotic). Further investigation along these lines may prove to be very exciting. ${ }^{53}$

\section{J VLACHOGIANNAKOS}

A K W TANG D PATCH

A K BURROUGHS Liver Transplantation and Hepatobiliary Medicine, Royal Free Hospital, London, UK

Correspondence to: Dr A K Burroughs, Liver Transplantation and Hepatobiliary Medicine, Royal Free Hospital, Pond Street, London NW3 2QG, UK. andrew.burroughs@talk21.com
1 Armonis A, Patch D, Burroughs A. Hepatic venous pressure: an old test as a new prognostic marker in cirrhosis? Hepatology 1997;25:245-8.

2 Lebrec D. Pharmacological treatment of portal hypertension: present and future. F Hepatol 1998;28:896-907.

3 Reichen J. Liver function and pharmacological consideratons in pathogenesis and treatment of portal hypertension. Hepatology 1990;11:1066-78.

4 Vlachogiannakos J, Goulis J, Patch D, et al. Primary prophylaxis for portal hypertensive bleeding in cirrhosis. Aliment Pharmacol Ther 2000;14:85160.

5 Lebrec D, Poynard T, Bernuau J, et al. A randomized controlled study of propranolol for prevention of recurrent gastrointestinal bleeding in patients propranolol for prevention of recurrent gastrointestinal
with cirrhosis: a final report. Hepatology 1984;4:355-8.

6 Groszmann RJ, Bosch J, Grace ND, et al. Hemodynamic events in a prospective randomized trial of propranolol versus placebo in the prevention of a first variceal hemorrhage. Gastroenterology 1990;99:1401-7.

7 Garcia-Tsao G, Grace ND, Grozmann RJ, et al. Short-term effects of propranolol on portal venous pressure. Hepatology 1986;6:101-6.

8 Sims DE. The pericyte-a review. Tissue Cell 1986;18:153-74

9 Marra F. Hepatic stellate cells and the regulation of liver inflammation. 7 Hepatol 1999;31:1120-30.

10 Rockey D. The cellular pathogenesis of portal hypertension: stellate cell contractility, endothelin, and nitric oxide. Hepatology 1997;25:2-5.

11 Epstein $M$. The renin-angiotensin system in liver disease. In: Epstein M, ed. The kidney in liver disease. New York: Elsevier Biomedical, 1983:353-75.

12 Arroyo V, Bosch J, Mauri M, et al. Renin, aldosterone and renal haemodynamics in cirrhosis with ascites. Eur f Clin Invest 1979;9:69-73.

13 Garcia-Pagan JC, Bosch J, Rodes J. The role of vasoactive mediators in portal hypertension. Semin Gastrointest Dis 1995;6:140-7.

14 Ballet F, Chretien Y, Rey C, et al. Differential response of normal and cirrhotic liver to vasoactive agents. A study in the isolated perfused rat liver. f Pharmacol Exp Ther 1988;244:233-5.

15 Goodfriend TL, Elliott ME, Catt KJ. Angiotensin receptors and their antagonists. $N$ Engl F Med 1996;25:1649-54.

16 Pinzani M, Falli P, Ruocco C, et al. Fat-storing cells as liver specific pericytes. Spatial dynamics of agonist-stimulated intracellular calcium transients. F Clin Invest 1992;90:642-6.

17 Laragh JH, Angers M, Kelly WG, et al. Hypotensive agents and pressor substances: the effect of epinephrine, norepinephrine, angiotensin II, and others on the secretory rate of aldosterone in man. FAMA 1960;174:23440

18 Nussberger J, Waeber B, Brunner HR. Clinical pharmacology of ACE inhibition. Cardiology 1989;76(suppl 2):11-22.

19 Burnier M, Brunner HR. Angiotensin II receptor antagonists. Lancet 2000; 355:637-45.

20 Schneider AW, Kalk JF, Klein CP. Effect of losartan, an angiotensin II receptor antagonist, on the portal pressure in cirrhosis. Hepatology 1999;29: 334-9.

21 Debernardi-Venon W, Barletti C, Marzano A, et al. Efficacy of irbesartan, an angiotensin II receptor selective antagonist, in the treatment of portal angiotensin II receptor selective antago
hypertension. Hepatology 1999;30:219A.

22 Ohnishi A, Ishizaki T, Murakami S, et al. Intrapatient comparison of acute hemodynamic, hormonal, and natriuretic responses to captopril versus enalapril in liver cirrhosis. Clin Pharmacol Ther 1990;48:67-75.

23 Pariente EA, Bataille C, Bercoff E, et al. Acute effect of captopril on systemic and renal haemodynamics and on renal function in cirrhotic patients with ascites. Gastroenterology 1985;88:1255-9.

24 Daskalopoulos G, Pinzani M, Murray N, et al. Effect of captopril on renal function in patients with cirrhosis and ascites. F Hepatol 1987;4:330-6.

25 Gentilini P, Romanelli RG, Villa GL, et al. Effect of low-dose captopril on renal haemodynamics and function in patients with cirrhosis of liver. Gastroenterology 1993;104:588-94.

26 Girgrah N, Liu P, Collier L, et al. Haemodynamic, renal sodium handling, and neurohormonal effects of acute administration of low dose losartan, an angiotensin II receptor antagonist, in preascitic cirrhosis. Gut 2000;46:11420

27 Saruta T, Eguchi T, Saito I. Angiotensin antagonist in liver disease. In: Epstein $\mathrm{M}$, ed. The kidney in liver disease, 2nd edn. New York: Elsevier, 1983:441-50.

28 Brunkhorst R, Wrenger E, Kühn K, et al. Effect of captopril therapy on sodium and water excretion in patients with liver cirrhosis and ascites. Klin Wochenschr 1989;67:774-83.

29 Ibarra FR, Afione C, Garzon D, et al. Portal pressure, renal function and hormonal profile after acute and chronic captopril treatment in cirrhosis. Eur f Clin Pharmacol 1992;43:477-82.

30 Van Vliet AA, Donker AJ, Meuwissen SG. Efficay of low-dose captopril in addition to frusemide and spirololactone in patients with decompensated liver disease during blunt diuresis. F Hepatol 1992;15:40-7.

31 Wood LJ, Goergen S, Stockigt JR, et al. Adverse effects of captopril in treatment of resistant ascites, a state of functional bilateral renal artery stenosis. Lancet 1985;2:1008-9.

32 Tsai YT, Lin HC, Lee FY, et al. Effect of captopril on renal functions, renal and portal haemodynamics in patients with cirrhosis. Proc Natl Sci Counc, Repub China B 1996;20:44-50.

33 Ohnishi A, Murakami S, Harada M, et al. Renal and hormonal responses to repeated treatment with enalapril in non-azotemic cirrhosis with ascites. $\mathcal{F}$ Hepatol 1994;20:223-30.

34 Amarapurkar DN, Dhawan P, Kalro RH. Role of routine estimation of creatinine clearance in patients with liver cirrhosis. Indian 7 Gastroenterol 1994;13:79-82.

35 Schrier RW, Arroyo V, Bernardi M, et al. Peripheral arterial vasodilatation hypothesis: a proposal for the initiation of renal sodium and water retention in cirrhosis. Hepatology 1988;8:1151-7.

36 Hall JE, Guyton AC, Jackson TE, et al. Control of glomerular filtration rate by renin-angiotensin system. Am F Physiol 1977;233:F366-72.

37 Schrier RW. Renin-angiotensin in preascitic cirrhosis: Evidence for primary peripheral arterial vasodilatation. Gastroenterology 1998;115:489-91.

38 Wong F, Sniderman K, Blendis L. The renal sympathetic and reninangiotensin response to lower body negative pressure in well-compensated cirrhosis. Gastroenterology 1998;115:397-405.

39 Helmy A, Jalan R, Newby DE, et al. Role of angiotensin II in regulation of basal and sympathetically stimulated vascular tone in early and advanced cirrhosis. Gastroenterology 2000;118:565-72. 
40 Eriksson LS, Kagedal B, Wahren J. Effect of captopril on hepatic venous pressure and blood flow in patients with liver cirrhosis. Am 7 Med 1984;76: pressure

41 Chiang HT, Cheng JS, Lin M, et al. Haemodynamic effect of enalaprilat on portal hypertension in patients with HBsAg-positive cirrhosis. 7 Gastroenterol Hepatol 1995;10:256-60.

42 Svoboda P, Ochmann J, Kantorova I. Effect of enalapril treatment and sclerotherapy of esophageal varices on hepatic haemodynamics in portal hypertension. Hepatogastroenterology 1992;39:549-52.

43 Atlas SA, Case DB, Yu ZY, et al. Hormonal and metabolic effects of angiotensin converting enzymes inhibitors. Possible differences between enalapril and captopril. Am f Med 1984;2077:13-17.

44 Johnston CJ, Clappison BH, Anderson WP, et al. Effect of angiotensinconverting enzyme inhibition on circulating and local kinins levels. $A m \mathcal{F}$ Cardiol 1982;49:1401-4

45 Arroyo V, Bosch J, Maori M, et al. Effect of angiotensin II blockade on systemic and hepatic hemodynamics and on renin-angiotensin-aldosterone
system in cirrhosis with ascites. Eur 7 Clin Invest 1981;1:221-9.

46 Garcia-Tsao G. Angiotensin II receptor antagonists in the pharmacological therapy of portal hypertension: a caution. Gastroenterology 1999;117:740-2.
47 Goa KL, Wagstaff AJ. Losartan potassium: a review of its pharmacology, clinical efficacy and tolerability in the management of hypertension. Drugs clinical efficacy a

48 Bhathal PS, Grossman HJ. Reduction of the increased portal vascular resistance of the isolated perfused cirrhotic rat liver by vasodilators. $\mathcal{F}$ Hepatol 1985;1:325-37.

49 Schepke M, Werner E, Bicker E, et al. The angiotensin II receptor antagonist irbesartan for the treatment of portal hypertension: a placebo controlled, double-blind study. Hepatology 2000;32:406A.

50 Bataller R, Gines P, Nicolas JM, et al. Angiotensin II induces contraction and proliferation of human hepatic stellate cells. Gastroenterology 2000;118: 1149-56.

51 Rockey DC, Weisiger RA. Endothelin induced contractility of stellate cells from normal and cirrhotic liver: implications for regulation of portal pressure and resistance. Hepatology 1996;24:233-40.

52 Yoo KH, Thornhill BA, Wolstenholme JT, et al. Tissue-specific regulation of growth factors and clusterin by angiotensin II. Am $\mathcal{f}$ Hypertens 1998;11:715-22.

53 Rockey DC. Vasoactive agents in intrahepatic portal hypertension and fibrogenesis: implications for therapy. Gastroenterology 2000;118:1261-5.

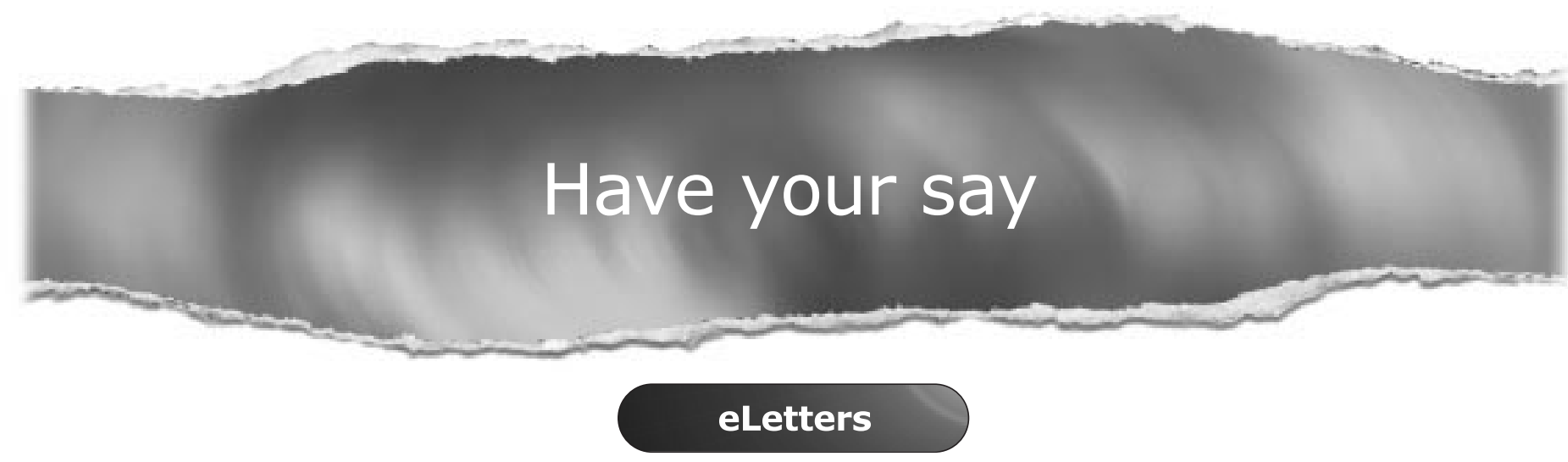

If you wish to comment on any article published in Gut you can send an eLetter using the eLetters link at the beginning of each article. Your response will be posted on Gut online within a few days of receipt (subject to editorial screening).

www.gutjnl.com 